\title{
Application of Single Strand Conformation Polymorphism - PCR method for distinguishing cheese bacterial communities that inhibit Listeria monocytogenes
}

\author{
M. Saubusse, L. Millet, C. Delbès, C. Callon, M.C. Montel* \\ Unité de Recherches Fromagères URF 545, INRA, F-15000 Aurillac, France
}

Received 14 June 2006; received in revised form 17 November 2006; accepted 18 December 2006

\begin{abstract}
The aim of this study was to compare the microbial communities of different cheeses where Listeria monocytogenes either grew or did not grow. For this purpose, (i) isolates from the most inhibitory cheese ecosystem were identified and their ability to produce anti-Listeria substances was determined, (ii) bacterial communities of cheeses with and without L. monocytogenes growth were compared using the Single Strand Conformation Polymorphism method.

The study showed SSCP to be an effective tool for differentiating between the bacterial communities of different cheeses manufactured with the same technology. All the cheeses with the lowest L. monocytogenes counts on day 8 were distinguished by the dominance in their SSCP profiles, after amplification of the V2 region of the 16S rRNA gene, of 3 peaks whose nucleotide sequences comigrated with Enterococcus faecium and Enterococcus saccharominimus, Chryseobacterium sp and Corynebacterium flavescens, Lactococcus garvieae and Lactococcus lactis respectively. However, no anti-Listeria compounds were produced under our experimental conditions.

These six bacterial species were inoculated, separately or together, into pasteurised milk and their anti-listerial activity in cheese was evaluated. The area of inhibition between the control and trial curves confirmed that L. monocytogenes is inhibited by E. saccharominimus, C. flavescens, L. lactis, L. garvieae and the mixture of all six bacterial strains.

Further studies should be performed to determine the metabolites involved in L. monocytogenes inhibition. (C) 2007 Elsevier B.V. All rights reserved.
\end{abstract}

Keywords: Listeria monocytogenes; Inhibition; Raw-milk cheeses; SSCP; Anti-Listeria compounds

\section{Introduction}

The safety of dairy products has been greatly improved throughout the food production chain by the implementation of Good Manufacturing Practices (GMP) and Good Hygienic Practices (GHP) and by the development and increasing application of the semi-quantitative Hazard Analysis Critical Control Point (HACCP) system in "farm-to-fork" systems.

\footnotetext{
* Corresponding author. Unité de Recherches Fromagères INRA, 36 rue de Salers, 15000 Aurillac, France. Tel.: +33 4714564 10; fax: +33 471 456413.

E-mail address: cmontel@clermont.inra.fr (M.C. Montel).
}

Safety can also be improved by eliminating milk pathogens by pasteurising or microfiltering raw milk. However, processing milk in these ways may have adverse effects on the typical organoleptic and sensory characteristics of traditional cheeses and does not prevent contamination by certain pathogens such as Listeria monocytogenes. Bio-preservation strategies based on the addition of inhibitory bacterial strains have been widely studied. Selecting bacterial strains that produce nisin (Maisnier-Patin et al., 1992; Olasupo et al., 1999) or other bacteriocins (Nunez et al., 1997; Ennahar and Deschamps, 2000; Buyong et al., 1998; Loessner et al., 2003) and/or organic acids (Ramsaran et al., 1998; Morgan et al., 2001; Millet et al., 2006) has been investigated as a method for inhibiting L. monocytogenes growth in cheeses. However, effective applications are scarce and the long-term effectiveness 
of inhibitory strains has been questioned, mainly because of the occurrence of pediocin- and nisin-resistant pathogenic strains (Gravesen et al., 2002). A promising strategy could result from recent studies based on the hypothesis that natural flora can compete with food pathogens in cheese. Indeed, it has been shown that some ripening consortia from smear-ripened cheese (Maoz et al., 2003), and microbial communities from raw milk (Millet et al., 2006; Gay and Amgar, 2005) can inhibit L. monocytogenes.

The mechanism of inhibition in smear-ripened cheeses has yet to be understood (Maoz et al., 2003). The inhibition observed by Millet et al. (2006) in some raw-milk cheeses may be partly due to lower $\mathrm{pH}$ and acid production, but the microbial populations involved have not been identified. In complex cheese ecosystems, one method for identifying the populations involved in inhibition is to isolate the different strains that make up the bacterial community with anti-Listeria properties (Maoz et al., 2003). Such an approach is time-consuming and the strains may behave quite differently in laboratory media and in food products. A new approach for identifying the microbial populations associated with inhibition can be proposed, based on comparing the microbial communities of raw-milk cheeses where $L$. monocytogenes grows while others do not. This can be achieved by applying molecular tools that help describe the dynamics of microbial communities as a whole without having to culture any micro-organisms. Among these techniques, Temporal Temperature and Denaturing Gradient Gel Electrophoresis (TTGE and DGGE) (Cocolin et al., 2004; Ercolini et al., 2004; Ogier et al., 2004) and Single Strand Conformation Polymorphism (SSCP) (Duthoit et al., 2003,2005 ) have been applied to food microbial ecology with increasing success.

The aim of this study was to identify microbial populations which can be involved in the inhibition of L. monocytogenes in cheeses previously studied by Millet et al. (2006). Two approaches were combined for this purpose. In the first, the isolates from most of the inhibitory cheese ecosystem were identified and their ability to produce anti-Listeria substances was determined. In the second, the SSCP method was used to compare the bacterial communities of cheeses with and without L. monocytogenes growth.

\section{Materials and methods}

\subsection{Cheese samples}

The cheese samples were those studied by Millet et al. (2006). As described by those authors, they were manufactured according to a Saint-Nectaire type technology using raw milk from six different farms (F1, F2, F3, F4, F5 and F6). With each milk, cheese was made three times over a one-month period. This study specifically investigated cheeses ripened for 8 days, because the differences in L. monocytogenes counts have been shown to be greatest after this ripening period. Moreover, most of the microbial flora counted in different media have been shown to be at the highest level at day 8 (Millet et al., 2006). Two groups of cheeses were selected according to their respective L. monocytogenes counts. The first group, the F1, F2 and F3 cheeses, consisted of those with the highest L. monocytogenes counts, ranging between 1.26 and $3.58 \log (\mathrm{CFU} / \mathrm{ml})$. The second group, F3, F4 and F5, had the lowest L. monocytogenes counts ( 0.1 to $2.31 \log \mathrm{CFU} / \mathrm{ml})$.

\subsection{Total genomic DNA extraction}

Total genomic DNA was extracted from $1 \mathrm{~g}$ cheese samples on day 8 by a phenol-chloroform method including treatment with zirconium beads as described by Duthoit et al. (2003).

\subsection{PCR amplification}

Total DNA extracted from cheeses sampled on day 8 was amplified with two sets of primers (Table 1): w34-w49 and V2F-V2R.

Forward primers w49 and V2F were labelled with $5^{\prime}$-fluorescein phosphoramidite HEX and reverse primers w34 and V2R with 3 '-fluorescein phosphoramidite NED. All the primers were synthesised by Applied Biosystems (Foster City, USA).

PfuUltra $^{\text {TM }}$ High-Fidelity DNA polymerase (Stratagene Europe, Amsterdam Zuidoost, Netherlands) was used for all PCR amplifications. PCR was performed in a total volume of $25 \mu \mathrm{l}$ containing $10 \mu \mathrm{M}$ of each primer, $0.2 \mathrm{mM}$ of each deoxynucleoside triphosphate, $1 \mu \mathrm{l}$ of cheese-extracted DNA, $1 \times$ buffer and $1.25 \mathrm{U}$ of PfuUltra ${ }^{\mathrm{TM}}$ High-Fidelity polymerase.

All the reaction mixtures were subjected to 30 amplification cycles in a thermocycler model 9700 (Perkin Elmer, Applied Biosystems, Foster City, USA). PCR amplification conditions are reported in Table 1. PCR products were electrophoresed on a $0.8 \%$ agarose gel, in $0.5 \times$ Tris borate EDTA buffer $(89 \mathrm{mM}$

Table 1

PCR primers and amplification conditions used in this study

\begin{tabular}{|c|c|c|c|}
\hline Primers & Sequence & $\begin{array}{l}\text { Amplification } \\
\text { conditions }\end{array}$ & References \\
\hline w34 & TTACCGCGGCGTGCTGGCAC & $3 \min$ at $96^{\circ} \mathrm{C}$ & $\begin{array}{l}\text { Zumstein et al } \\
(2000)\end{array}$ \\
\hline w49 & ACGGTCCAGACTCCTACGGG & $\begin{array}{l}30 \text { cycles of: } \\
30 \mathrm{~s} \text { at } 96^{\circ} \mathrm{C} ; \\
30 \mathrm{~s} \text { at } 61^{\circ} \mathrm{C} ; \\
30 \mathrm{~s} \text { at } 72^{\circ} \mathrm{C} ; \\
10 \text { min at } 72^{\circ} \mathrm{C}\end{array}$ & $\begin{array}{l}\text { Delbes et al. } \\
\text { (1998) }\end{array}$ \\
\hline V2F & CGCGAACGGGTGAGTAA & $3 \min$ at $96^{\circ} \mathrm{C}$ & $\begin{array}{l}\text { Duthoit et al. } \\
\text { (2003) }\end{array}$ \\
\hline V2R & ACTGCTGCCTCCCGTAG & $\begin{array}{l}30 \text { cycles of: } \\
30 \mathrm{~s} \text { at } 96^{\circ} \mathrm{C} ; \\
30 \mathrm{~s} \text { at } 55^{\circ} \mathrm{C} ; \\
45 \mathrm{~s} \text { at } 72^{\circ} \mathrm{C} ; \\
10 \text { min at } 72^{\circ} \mathrm{C}\end{array}$ & $\begin{array}{l}\text { Duthoit et al. } \\
\text { (2003) }\end{array}$ \\
\hline w02 & NTACCTTGTTACGACTT & 5 min at $96^{\circ} \mathrm{C}$ & $\begin{array}{l}\text { Godon et al. } \\
\text { (1997) }\end{array}$ \\
\hline w18 & GAGTTTGATCMTGGCTCAG & $\begin{array}{l}25 \text { cycles of: } \\
60 \mathrm{~s} \text { at } 96^{\circ} \mathrm{C} ; \\
30 \mathrm{~s} \text { at } 50^{\circ} \mathrm{C} ; \\
60 \mathrm{~s} \text { at } 72^{\circ} \mathrm{C}\end{array}$ & $\begin{array}{l}\text { Godon et al. } \\
\text { (1997) }\end{array}$ \\
\hline
\end{tabular}


Table 2

Agar media, incubation time and incubation temperature used in this study

\begin{tabular}{|c|c|c|c|}
\hline & $\begin{array}{l}\text { Incubation time/ } \\
\text { temperature }\left({ }^{\circ} \mathrm{C}\right)\end{array}$ & & References \\
\hline Medium 17 (M17) & $72 \mathrm{~h}$ & 30 & $\begin{array}{l}\text { Terzaghi and Sandine } \\
\text { (1975) }\end{array}$ \\
\hline Medium 17 & $48 \mathrm{~h}$ & 42 & $\begin{array}{l}\text { Terzaghi and Sandine } \\
\text { (1975) }\end{array}$ \\
\hline $\begin{array}{l}\text { Rabbit Plasma } \\
\text { Fibrinogen (RPF) }\end{array}$ & $24 \mathrm{~h}$ & 37 & De Buyser et al. (2003) \\
\hline Slanetz Bartley (SB) & $48 \mathrm{~h}$ & 42 & $\begin{array}{l}\text { Slanetz and Bartley } \\
\text { (1957) }\end{array}$ \\
\hline $\begin{array}{l}\text { Oxytetracycline Glucose } \\
\text { Agar (OGA) }\end{array}$ & from 3 to 4 days & 25 & FIL-IDF 94B (1991) \\
\hline $\begin{array}{l}\text { Cephalidine Fucidine } \\
\text { Cetramidine (CFC) }\end{array}$ & from 48 to $72 \mathrm{~h}$ & 25 & NF V 04-504 (1988) \\
\hline $\begin{array}{l}\text { Facultatively } \\
\text { Heterofermentative }(\mathrm{FH})\end{array}$ & $72 \mathrm{~h}$ & 30 & Isolini et al. (1990) \\
\hline Turner (T) & $72 \mathrm{~h}$ & 30 & Turner et al. (1963) \\
\hline Turner + nalidixic acid $(\mathrm{T}+$ n.a. $)$ & $72 \mathrm{~h}$ & 30 & Turner et al. (1963) \\
\hline $\begin{array}{l}\text { Plate Count Agar + Milk } \\
\quad(\mathrm{PCA}+\mathrm{M})\end{array}$ & 3 days & 30 & FIL-IDF 100B \\
\hline $\begin{array}{l}\text { PCA }+\mathrm{M}+\text { Gram-positive } \\
\text { inhibitory }\end{array}$ & 3 days & 30 & FIL-IDF 100B \\
\hline Nickels and Leesment (NL) & $72 \mathrm{~h}$ & 25 & Vogensen et al. (1987) \\
\hline $\begin{array}{l}\text { Mayeux Sandine } \\
\text { Elliker (MSE) }\end{array}$ & $72 \mathrm{~h}$ & 30 & Mayeux et al. (1962) \\
\hline $\begin{array}{l}\text { Cheese Ripening Bacteria } \\
\text { Medium (CRBM) }\end{array}$ & 5 and 10 days & 25 & Denis et al. (2001) \\
\hline $\begin{array}{l}\text { Violet Red Bile Glucose } \\
\text { (VRBG) agar }\end{array}$ & $24 \mathrm{~h}$ & 42 & NF V 08-021 (1985) \\
\hline
\end{tabular}

All the media were incubated aerobically except the FH medium which was incubated anaerobically.

Tris base, $89 \mathrm{mM}$ borate, $2 \mathrm{mM}$ EDTA) containing 5\% ethidium bromide. DNA bands were visualised under UV light.

\subsection{SSCP capillary electrophoresis}

PCR products were purified with a Strata Prep ${ }^{\text {TMPCR puri- }}$ fication Kit (Stratagene Europe, Amsterdam Zuidoost, Netherlands) following the manufacturer's recommendations.

A mixture containing $18.75 \mu \mathrm{l}$ deionised formamide (Applied Biosystems, Foster City, USA), $0.25 \mu 1$ internal DNA molecular weight standard Genescan 400 HD Rox (Applied Biosystems, Foster City, USA) and $1 \mu 1$ purified PCR product was denatured for $5 \mathrm{~min}$ at $95^{\circ} \mathrm{C}$ and immediately cooled on ice. The mixture was then electrophoresed by SSCP capillary electrophoresis on an ABI Prism 310 genetic analyser (Applied Biosystems, Foster City, USA) as described by Duthoit et al. (2003).

\subsection{Assignation of dominant peaks}

Dominant peaks in the SSCP patterns were assigned by comparing their migration with the migration of cloned $16 \mathrm{~S}$ rRNA gene sequences, or reference strains, or bacterial strains isolated from Saint-Nectaire cheese, or bacterial strains isolated from retentate raw-milk F5.
A clone library was prepared using genomic DNA extracted from the cheese sample showing the highest number of peaks on its SSCP profile. The 16S rRNA gene was amplified with universal primers $\mathrm{w} 02$ and w18. In a total volume of $50 \mu 1$, the PCR mixture contained $10 \mathrm{mM}$ Tris $\mathrm{HCl}(\mathrm{pH} 8.5), 25 \mathrm{mM} \mathrm{KCl}$, $5 \mathrm{mM}\left(\mathrm{NH}_{4}\right) 2 \mathrm{SO}_{4}, 2 \mathrm{mM} \mathrm{MgSO} 4,0.1 \mu \mathrm{M}$ of each primer, $0.2 \mathrm{mM}$ of each deoxynucleoside triphosphate, $1 \mathrm{U}$ of Pwo polymerase (Roche, Applied Science Division, Meylan Cedex, France) and $2 \mu \mathrm{l}$ of extracted DNA. Amplification was performed as indicated in Table 1.

The amplified product was cloned into pCR-Blunt-IITOPO vector and transformed in Escherichia coli cells following the manufacturer's instructions (Invitrogen SARL, Cergy Pontoise Cedex, France). Plasmid inserts of 94 clones were amplified by PCR with M13 forward and M13 reverse

Table 3

List of microbial species assigned on the basis of over $98 \%$ similarity between their partial 16S rRNA sequences and those in databases (NCBI databases using the BLAST program)

\begin{tabular}{|c|c|c|c|}
\hline Bacteria & $\mathrm{ni}$ & & \\
\hline Lactococcus lactis & 10 & \multirow{14}{*}{$\begin{array}{l}\text { Lactic } \\
\text { bacteria }\end{array}$} & \multirow{32}{*}{$\begin{array}{l}\text { Gram- } \\
\text { positive } \\
\text { bacteria }\end{array}$} \\
\hline Lactococcus garvieae & 7 & & \\
\hline Enterococcus faecalis & 20 & & \\
\hline Enterococcus saccharominimus & 8 & & \\
\hline Enterococcus malodoratus & 1 & & \\
\hline Enterococcus hirae & 1 & & \\
\hline Lactobacillus casei & 1 & & \\
\hline Lactobacillus plantarum & 2 & & \\
\hline Lactobacillus farciminis & 2 & & \\
\hline Lactobacillus parabuchneri & 2 & & \\
\hline Lactobacillus paracase & 3 & & \\
\hline Lactobacillus curvatus & 4 & & \\
\hline Leuconostoc citreum & 4 & & \\
\hline Leuconostoc pseudomesenteroides & 1 & & \\
\hline Staphylococcus aureus & 9 & \multirow{18}{*}{$\begin{array}{l}\text { Non-lactic } \\
\text { bacteria }\end{array}$} & \\
\hline Staphylococcus xylosus & 4 & & \\
\hline Staphylococcus saprophyticus & 1 & & \\
\hline Staphylococcus equorum & 3 & & \\
\hline Staphylococcys xylosus or & 1 & & \\
\hline Staphylococcus equorum & & & \\
\hline Arthrobacter nicotianae & 1 & & \\
\hline Microbacterium sp. & 1 & & \\
\hline Corynebacterium flavescens & 1 & & \\
\hline Corynebacterium casei & 1 & & \\
\hline Brevibacterium linens & 1 & & \\
\hline Rothia sp. & 1 & & \\
\hline Macrococcus caseolyticus & 1 & & \\
\hline Brachybacterium rhamnosus & 1 & & \\
\hline Brachybacterium alimentarium & 1 & & \\
\hline Kocuria sp. & 3 & & \\
\hline Kocuria rhizophilia & 1 & & \\
\hline Exiguobacterium sp. & 2 & & \\
\hline Pseudomonas sp & 1 & & \multirow{9}{*}{$\begin{array}{l}\text { Gram- } \\
\text { negative } \\
\text { bacteria }\end{array}$} \\
\hline Pseudomonas umsongensis & 1 & & \\
\hline Pseudomonas putida & 16 & & \\
\hline Stenotrophomonas malptophilia & 2 & & \\
\hline Enterobacter amnigenus & 14 & & \\
\hline Enterobacter sp. & 3 & & \\
\hline Chryseobacterium sp. & 7 & & \\
\hline Comamonas testoteroni & 1 & & \\
\hline Acinetobacterium sp. & 2 & & \\
\hline
\end{tabular}

ni: number of isolates. 
primers. The $16 \mathrm{~S}$ rRNA gene clones were sequenced with primer w34 on an ABI prism 310 genetic analyser (Applied Biosystems, Foster City, USA) using the Big Dye Terminator cycle sequencing kit (Applied Biosystems, Foster City, USA). Each sequence (approximately $300 \mathrm{bp}$ ) was compared with sequences in the GenBank database, using the NCBI BLAST program.

\subsection{Statistical analysis}

The proportion of peaks present in the SSCP profiles obtained with each primer was calculated using the following formula: $P_{\mathrm{i}}=a_{\mathrm{i}} * 100 / \sum a_{\mathrm{i}}$, where $\mathrm{P}_{\mathrm{i}}$ was the ratio of peaks and $a_{\mathrm{i}}$ the area of one peak.

The relationship between the $P_{\mathrm{i}}$ values in the (V2F-V2R)SSCP profiles of cheeses on day 8 was shown as a dendrogram constructed by the Unweighted Pair Group Method using Average (UPGMA) with statistical software (StatSoft 2003, Statistica version 6.1, Tulsa, USA).

Principal Component Analyses (PCA) were carried out with the $P_{\mathrm{i}}$ values in the (Gram1F-Gram2R)-SSCP profiles of cheeses on day 8 using statistical software (StatSoft 2003, Statistica version 6.1, Tulsa, USA).

\subsection{Anti-Listeria activity assessment by the agar-well diffusion method}

The anti-Listeria activity of the raw-milk microbial community expressing the strongest Listeria-inhibiting potential in cheese according to Millet et al. (2006) was assessed. The raw milk was then microfiltered on an MFS-1 microfiltration pilot plant with a capacity of 600 1/h (Alpha-Laval, Les Clayes-sousBois, France) and the composition of the microbial retentate (raw-milk microbial fraction trapped in a $1.2-\mu \mathrm{m}$ pore membrane), which is representative of milk microbial community, was analysed. The various microbial populations composing the retentate were cultured in duplicate on 15 types of media (Table 2). All colonies grown on each nutrient agar medium were collected in a 5\% solution of sterile glycerol and stored at $-20{ }^{\circ} \mathrm{C}$ to be tested for their anti-Listeria activity as described below.

Ten to twelve colonies were also randomly picked from each duplicate culture agar medium, for identification. A total of 143 isolates were identified by sequencing approximately $300 \mathrm{bp}$ of the $5^{\prime}$ end of the $16 \mathrm{~S}$ rRNA gene (as described above) and comparing each sequence with sequences in GenBank using the NCBI BLAST program.

The whole colonies collected on different agar media and the isolates were each grown individually for $24 \mathrm{~h}$ in an appropriate broth medium and at a suitable incubation temperature. Culture broths were centrifuged at $5000 \mathrm{~g}$ for $15 \mathrm{~min}$ at $4{ }^{\circ} \mathrm{C}$. The $\mathrm{pH}$ of supernatants obtained was adjusted to $\mathrm{pH} 6$. Supernatants were filtered on a $0.45 \mu \mathrm{m}$ membrane filter (Minisart Sartorius, Hannover, Germany). The anti-listerial properties of the supernatants were tested using the Tagg and McGiven (1971) agar-well diffusion method modified by the use of a double agar layer. Petri dishes were filled with $20 \mathrm{ml}$ of neutral $\mathrm{pH}$ nutrient agar. The top layer consisted of $10 \mathrm{ml}$ of Trypticase Soja-Yeast Extract (TS-YE) agar medium previously inoculated with $0.1 \mathrm{ml}$ of an $18 \mathrm{~h}$-old TS-YE broth culture of L. monocytogenes. Holes $(\varnothing 6 \mathrm{~mm})$ were pierced through the top agar, the wells were filled with $0.1 \mathrm{ml}$ of culture filtrate and the $\mathrm{pH}$ was neutralised. The inoculated plates were incubated for $24 \mathrm{~h}$ at $37^{\circ} \mathrm{C}$. The diameter of the inhibition zone was measured.

\subsection{Anti-Listeria activity assessment in pasteurised milk cheeses}

The anti-listerial activities of some species were also evaluated by making pasteurised milk cheeses. The bacterial species tested were selected on the basis of the SSCP results.

All the milks pasteurised at $71{ }^{\circ} \mathrm{C}$ for $30 \mathrm{~s}$ were inoculated with the starter Streptococcus thermophilus at a concentration of $10^{7} \mathrm{CFU} / \mathrm{ml}$ and L. monocytogenes strain S2 at 5 to $10 \mathrm{CFU} /$ $25 \mathrm{ml}$. Other species were then inoculated individually into the pasteurised milks as follows.

Chryseobacterium spp., Enterococcus faecium and Enterococcus saccharominimus were inoculated at $10^{2} \mathrm{CFU} / \mathrm{ml}$, Corynebacterium spp. at $10^{3} \mathrm{CFU} / \mathrm{ml}$, Lactococcus lactis and Lactococcus garvieae at $10^{5} \mathrm{CFU} / \mathrm{ml}$. The level of inoculation was chosen according to their bacterial counts in milk F5 (Millet et al., 2006 and unpublished data). One milk was only inoculated with $S$. thermophilus to act as a control.

Prior to inoculation, all the bacteria were prepared as described above (see above, Anti-Listeria activity assessment by the agar-well diffusion method).

For each set of experiment, seven batches of cheeses were made with milks inoculated in this way, according to SaintNectaire type technology.

After one day of ripening, the cheeses were coated with an orange wax containing 1000 ppm of natamycin (Coquard, Villefranche sur Saône, France).

All cheeses were ripened for 28 days in INRA's ripening cellars under identical conditions, at $10{ }^{\circ} \mathrm{C}$ with $95 \%$ relative humidity.

The experiment was performed twice over a two-week period.

\subsection{Sampling and $p H$ determination of pasteurised milk cheeses}

The cheeses were sampled for microbial and chemical analysis on days $1,8,18$ and 28. For each cheese sample, $\mathrm{pH}$ was measured with a 926 VTV pH-meter with Ingold electrode 406 MX (Mettler-Toledo S.A., Viroflay, France). Cheese samples were prepared as described by Millet et al. (2006).

\subsection{Enumeration of bacteria in pasteurised milk cheeses}

L. monocytogenes concentrations were determined on PALCAM media. The genus and species of five presumed Listeria colonies were then confirmed according to norm ISO 11290-2.

Populations of $S$. thermophilus were enumerated on M17, Chryseobacterium spp. on PCA $+\mathrm{M}+\mathrm{I}$ medium (Table 2), 
E. saccharominimus and E. faecium on SB medium, Corynebacterium flavescens on CRBM medium, $L$. garvieae and $L$. lactis on $\mathrm{T}+$ a.n. medium in the incubation conditions indicated in Table 2.

\subsection{Calculation of area of inhibition}

In order to easily quantify the differences in L. monocytogenes population between treatment and control throughout ripening, the area of inhibition (AI) between two days ( $\mathrm{t} 1$ and t2) of ripening was calculated using the formula of Wenzel and Marth (1990):

$$
\mathrm{AI}=(\mathrm{t} 2-\mathrm{t} 1) / 2 \times\left[\left(C_{\mathrm{t} 2}+C_{\mathrm{t} 1}\right)-\left(T_{\mathrm{t} 2}+T_{\mathrm{t} 1}\right)\right]
$$

where

C count of L. monocytogenes in control cheese inoculated with $S$. thermophilus

$T \quad$ count of $L$. monocytogenes in trial cheese inoculated with $S$. thermophilus and other bacterial species.

\section{Results}

3.1. Identification of isolates and the production of antiListeria compounds by the raw-milk microbial community expressing the strongest Listeria-inhibiting potential in cheese

One hundred and forty-three isolates were assigned to a species, based on a $98 \%$ similarity between their partial $16 \mathrm{~S}$ rRNA gene sequences and those in the databases (NCBI databases using the BLAST program) (Table 3). Ninety-five isolates were identified as Gram-positive bacteria (63 lactic and 32 non-lactic bacteria), 48 as Gram-negative bacteria. The 143 isolates were classified into 41 microbial species.

With the agar-well diffusion method we used, none of the tests, either with individual isolates or with the retentate or with microbial populations collected on 15 agar media, produced any L. monocytogenes-inhibiting compound.

\subsection{SSCP patterns obtained with w34-w49 primers amplifying the $V 3$ region of the $16 S$ rRNA gene}

The various cheeses, prepared with three sets of experiments with each type of 6 different milks (F1 to F6), were analysed with primer pair w34-w49 on day 8 . The V3 region of the 16S rRNA gene of 16 cheeses was amplified. Comparison of the SSCP patterns obtained with these primers revealed a dominant peak, named $\mathrm{A}\left(P_{\mathrm{A}}>30 \%\right)$, in all SSCP profiles regardless of the cheese-making batch studied. As peak A was dominant and present in all SSCP patterns, it hampered the distinction of other, subdominant peaks that might have been useful for distinguishing between the different cheeses' bacterial communities (data not shown). The dominant peak corresponded to the S. thermophilus isolate sequence.

\subsection{SSCP patterns obtained with $V 2 F-V 2 R$ primers amplifying} the $V 2$ region of the $16 S$ rRNA gene

The different cheeses prepared with three sets of experiment with each type of 6 different milks (F1 to F6) were also obtained on days 1 and 8 with the V2F-V2R primer pair (Fig. 1). As there were no marked differences in SSCP profiles between days 1 and 8 and for the reasons explained in the Materials and methods section above, only SSCP profiles on day 8 were analysed. All the 8-day cheeses were classified in a dendrogram according to the SSCP pattern peak ratios obtained after amplifying the V2 region of the 16S rRNA gene (Fig. 2). The cheeses with the highest $L$. monocytogenes counts were clustered in 5 groups defined at an aggregative distance of 42: two cheeses prepared in two experiments from F2 and F3 were in group V and two cheeses from F1 were in group III. However, some F1, F2, F3 cheeses manufactured in the different experiments were in groups II or IV, indicating some variation in bacterial community composition from one cheese-making day to another. In contrast, cheeses with low L. monocytogenes counts $(<2.31 \mathrm{CFU} / \mathrm{g})$ were clustered in group I (F4, F5 and F6 cheeses from all three experiments). This clustering shows that the balance between the different populations in the bacterial communities of these cheeses, as amplified by the V2F-V2R primer pair, was stable from one cheese-making day to another.

Peak F was the dominant peak in the SSCP profiles of cheeses clustering in groups II and IV, but was proportionately smaller in the SSCP profiles of group I, III and V cheeses. There was no peak clearly characteristic of the cheeses with the highest L. monocytogenes counts. The cheeses in group I were distinctive in that peaks $\mathrm{C}, \mathrm{G}$ and $\mathrm{D}$ were dominant in their SSCP profiles, whereas these peaks were absent or subdominant in the SSCP profiles of cheeses in groups II to V.

Twenty-two clones were analysed to identify the peaks with the highest ratios in their SSCP profiles. Considering only $16 \mathrm{~S}$ rDNA sequences with at least $98 \%$ similarity with database sequences, $52 \%$ of clones were identified as S. thermophilus, $27 \%$ as L. lactis, $3 \%$ as Streptococcus parauberis and $14 \%$ as Streptococcus sp. As diversity was greater with isolate identification, the peaks were also assigned by comparing their migrations with those of the nucleotide sequences of the bacterial isolates and reference strains.

Peak F, whose ratios were among the highest in all SSCP patterns, comigrated with nucleotide sequences of $S$. thermophilus clones and isolates. Peak $\mathrm{C}$ comigrated with isolate sequences identified as E. faecium and E. saccharominimus, and peak $\mathrm{G}$ with Chryseobacterium sp. and C. flavescens isolate sequences. Similarly, peak D coeluted with nucleotide sequences of $L$. garvieae isolate and also with nucleotide sequences of clones and isolates of L. lactis.

\subsection{Evaluation of anti-listerial activity in pasteurised milk cheeses}

The fact that peaks $C, D$ and $G$ have the highest ratios on SSCP profiles of cheeses with the lowest $L$. monocytogenes counts suggests that the bacterial species corresponding to 
A
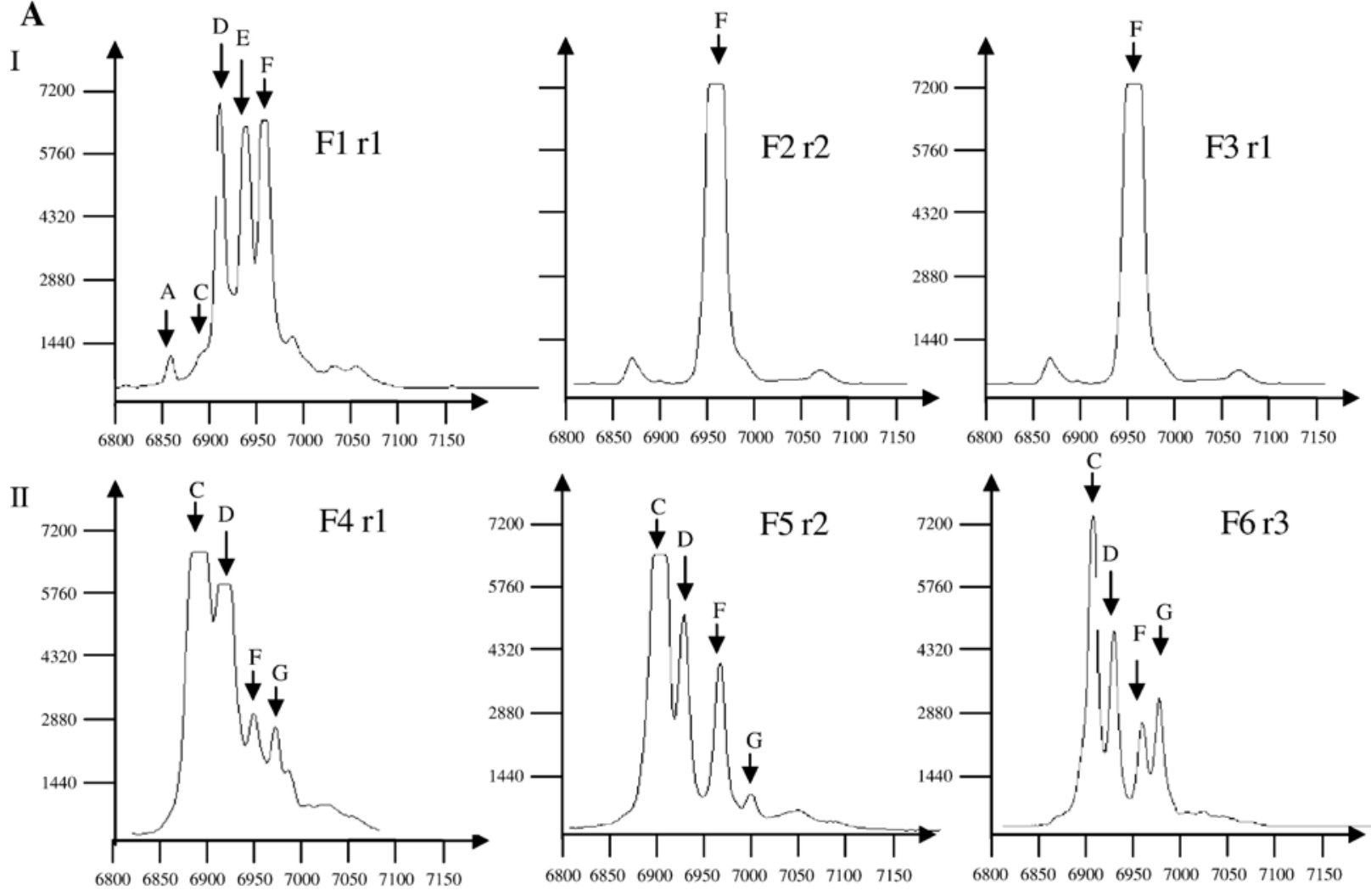

B
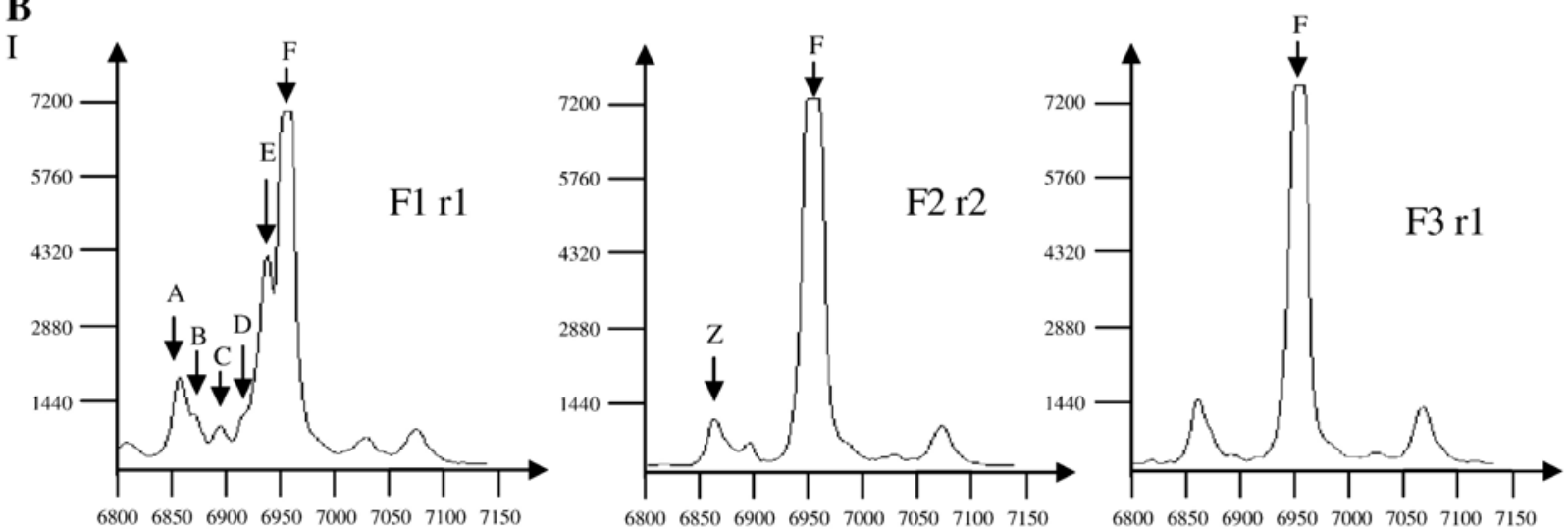

$\begin{array}{llllllll}6800 & 6850 & 6900 & 6950 & 7000 & 7050 & 7100 & 7150\end{array}$

$\begin{array}{llllllll}6800 & 6850 & 6900 & 6950 & 7000 & 7050 & 7100 & 7150\end{array}$

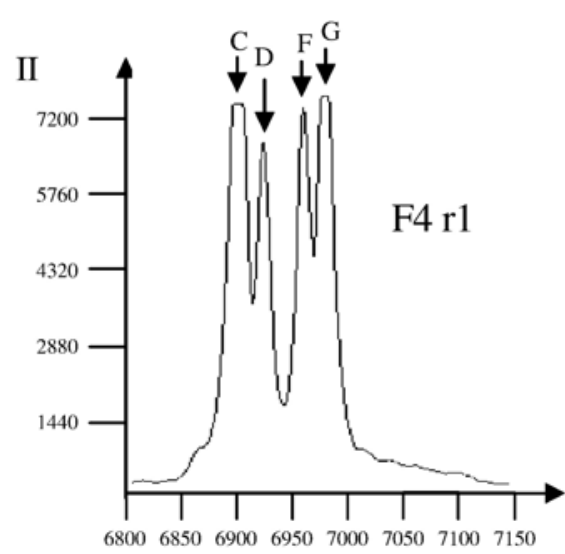

F6 r3

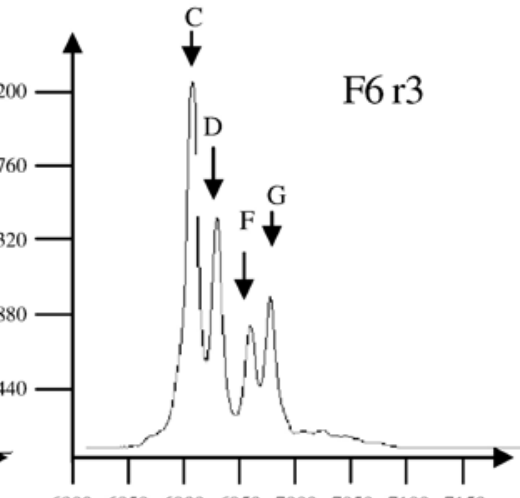

$\begin{array}{llllllll}6800 & 6850 & 6900 & 6950 & 7000 & 7050 & 7100 & 7150\end{array}$

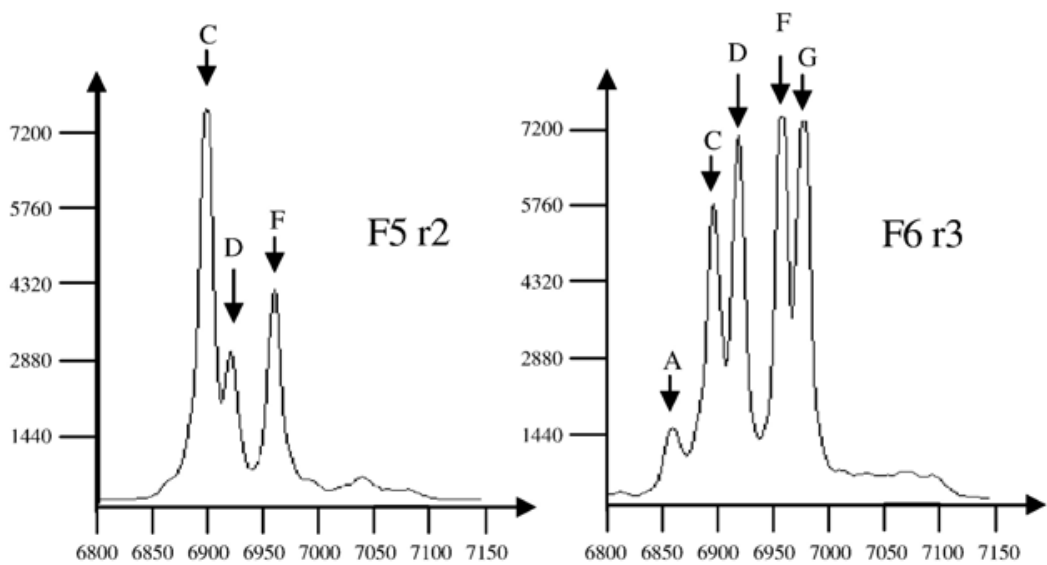

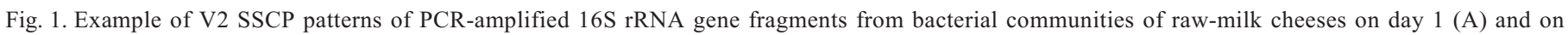

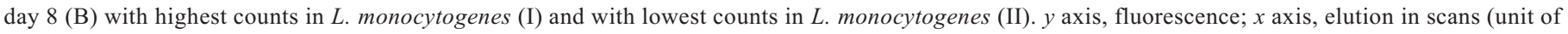
Genescan software). F $i$ ( $i$ from 1 to 6 ): origin farm of cheeses. rj ( $j$ from 1 to 3): experiment. Letters from A to G: name of peaks. 


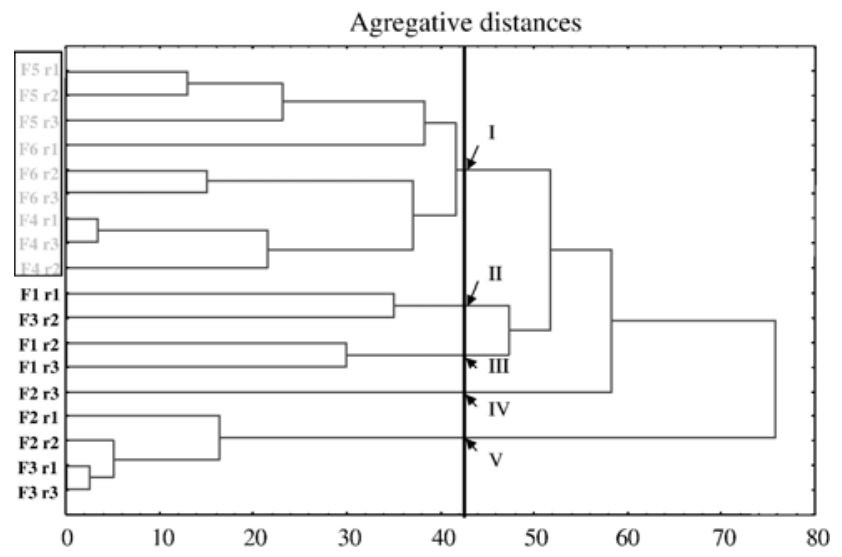

Fig. 2. Dendrogram of the distances (unweighted pair group average, Euclidean distances) between cheeses on day 8 of ripening. Classification of cheeses from the peak ratio data of their SSCP patterns of V2 region amplified 16S rRNA gene. Peak ratio data were calculated using the following formula: $P_{\mathrm{i}}=a_{\mathrm{i}}{ }^{*} 100 / \sum a_{\mathrm{i}}$, where $P_{\mathrm{i}}$ was the ratio of peaks and $a_{\mathrm{i}}$ the area of one peak. Fi ( $i$ from 1 to 6$)$ : origin farm of cheeses; $r j$ ( $j$ from 1 to 3 ): experiment. Fi r r framed and coloured in grey correspond to the name given to cheeses on day 8 with the lowest counts in L. monocytogenes.

these sequences may be involved in L. monocytogenes inhibition. To verify this hypothesis, the ability of E. faecium, E. saccharominimus, Chryseobacterium sp., C. flavescens, L. garvieae and L. lactis to inhibit L. monocytogenes was evaluated in pasteurised milk cheeses. Cheeses made from milk inoculated with $S$. thermophilus, the species that was dominant in cheeses with high L. monocytogenes counts, acted as a control. L. monocytogenes, S. thermophilus and all other bacteria in the cheeses were enumerated (Table 4). All the bacterial species developed mainly during the first day. After day 1, their counts remained more or less stable. The highest counts were observed for L. garvieae and L. lactis and the lowest for E. faecalis. E. saccharominimus was not detected under our counting conditions. Between days 18 and 28, C. flavescens showed weaker growth when inoculated in the mixture of 6 bacterial strains than when inoculated alone.

The development of L. monocytogenes was evaluated by calculating Area of Inhibition (AI) values as described in the Materials and methods section. The AI data and $\mathrm{pH}$ values are shown in Table 5. The higher the AI values, the stronger the inhibition of L. monocytogenes.

At day 1, AI values were not significantly different. After day 1, L. monocytogenes developed differently depending on the bacterial inoculation.

Throughout the ripening, L. monocytogenes AI values were the lowest in trial cheeses manufactured with Chryseobacterium sp. and E. faecium. After day 18, L. monocytogenes was not inhibited in presence of E. faecium $(\mathrm{AI}<0)$.

Between days 1 and 8 , AI values were significantly the highest in cheeses manufactured with $L$. lactis. Between days 8 and 18, L. monocytogenes was most inhibited (AI values highest) in presence of L. garvieae and the mixture of the 6 bacterial strains.
On days 1,8 and 28 , the $\mathrm{pH}$ values of the cheeses did not differ significantly. On day 18 , the $\mathrm{pH}$ value was significantly lowest in the control cheese, whose L. monocytogenes count was among the highest.

\section{Discussion}

The SSCP technique was successfully used for monitoring microbial community dynamics in cheeses (Duthoit et al., 2003). This study revealed that SSCP after DNA amplification with the proper primer set can also be an effective tool for distinguishing between cheese bacterial communities. The dominance of one peak on the SSCP profiles resulting from amplification of the V3 region of the 16S rRNA gene shows one of the limitations of the direct molecular approach when analysing bacterial communities in which one species is dominant. In the Saint-Nectaire cheeses studied, $S$. thermophilus was dominant since it is routinely used as a starter culture for Saint-Nectaire cheese. Amplification of the V2 region of the $16 \mathrm{~S}$ rRNA gene proved more relevant for distinguishing the bacterial communities of the different cheeses and for forming a hypothesis on the bacterial flora involved in the inhibition of L. monocytogenes. The only feature common to the cheeses with the highest $L$. monocytogenes counts was the peak assigned to $S$. thermophilus. Their SSCP profiles had no other common characteristics. By contrast, all the cheeses with the lowest L. monocytogenes counts on day 8 were characterised by the dominance of 3 peaks whose nucleotide sequences comigrated with E. faecium and E. saccharominimus, Chryseobacterium spp. and C. flavescens and L. garvieae and L. lactis sequences respectively. By inoculating these species in pasteurised milk with L. monocytogenes, it was shown that not all of them were able to inhibit it in cheeses prepared with these milks. Chryseobacterium spp. and E. faecium may not be involved in the inhibition under our experimental conditions. Inhibition occurred when L. lactis and L. garvieae were inoculated and, to a lesser extent, when E. saccharominimus and C.flavescens were inoculated. According to the literature, L. lactis can inhibit L. monocytogenes (1) by producing bacteriocins such as nisin and pediocin (Olasupo et al., 1999; Rodriguez et al., 2005), (2) by producing organic acids (Wenzel and Marth, 1990; Hicks and Lund, 1991) and (3) by lowering $\mathrm{pH}$ values as observed by Pitt et al. (2000) in pasteurised milk. However, our results reveal that L. monocytogenes inhibition was not due to a decrease of $\mathrm{pH}$ alone, nor to the ability of strains to produce anti-listerial compounds. Lowering $\mathrm{pH}$ values below 5.2 was not a sufficient condition to inhibit L. monocytogenes, although this value has been considered important for controlling L. monocytogenes in raw-milk Saint-Nectaire cheeses (Millet et al., 2006). A number of studies have found it difficult to identify the compounds involved in the inhibition of $L$. monocytogenes in cheeses. Maoz et al. (2003) failed to understand why L. monocytogenes was inhibited on cheese surfaces as the different microbial isolates of the inhibitory consortium exhibited no antilisterial activity. Gay and Amgar (2005) suggest that the microbial community had some role in explaining why L. monocytogenes developed less in raw-milk cheeses than in pasteurised milk cheeses but they did not study the nature of the inhibition ( $\mathrm{pH}$, organic acids, bacteriocins, etc.). 


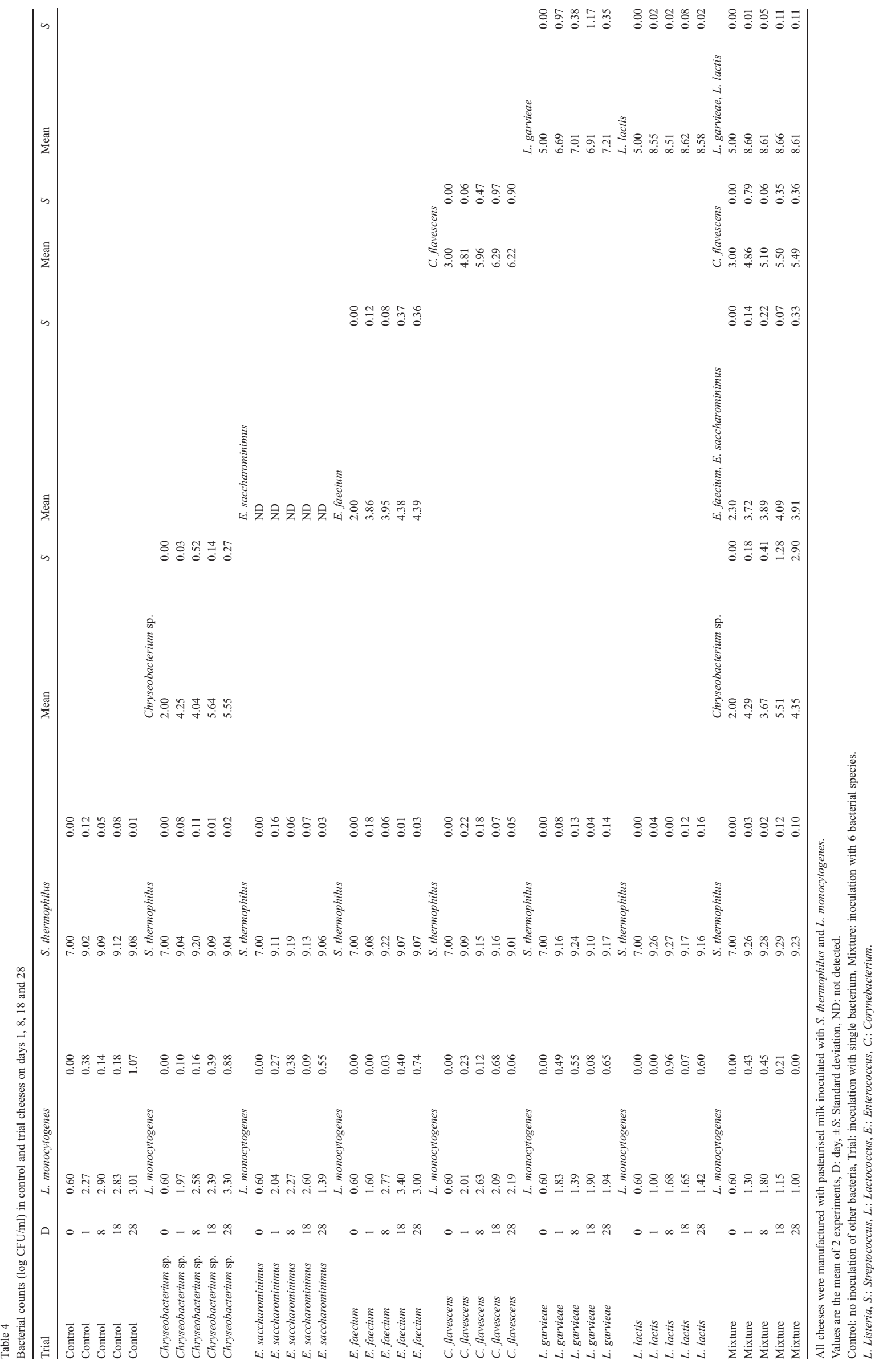


Table 5

$\mathrm{AI}$ and $\mathrm{pH}$ values in pasteurised milk cheeses

\begin{tabular}{lllll}
\hline Trial & AI $(1-0)$ & AI $(8-1)$ & AI $(18-8)$ & AI $(28-18)$ \\
\hline Chryseobacterium sp. & 0.15 & $2.94 \mathrm{ab}$ & $3.81 \mathrm{ab}$ & $0.78 \mathrm{ab}$ \\
E. saccharominimus & 0.12 & $2.09 \mathrm{a}$ & $5.61 \mathrm{ab}$ & $11.92 \mathrm{ab}$ \\
E. faecium & 0.33 & $2.78 \mathrm{a}$ & $2.23 \mathrm{a}$ & $-2.78 \mathrm{a}$ \\
Corynebacterium flavescens & 0.13 & $3.76 \mathrm{ab}$ & $3.76 \mathrm{ab}$ & $5.18 \mathrm{ab}$ \\
L. garvieae & 0.22 & $6.85 \mathrm{ab}$ & $12.19 \mathrm{~b}$ & $10.01 \mathrm{ab}$ \\
L. lactis & 0.64 & $8.72 \mathrm{~b}$ & $11.97 \mathrm{~b}$ & $13.83 \mathrm{ab}$ \\
Mixture & 0.49 & $7.26 \mathrm{ab}$ & $13.9 \mathrm{~b}$ & $18.45 \mathrm{~b}$ \\
$p$ & $\mathrm{NS}$ & $* *$ & $* *$ & $* *$ \\
& & & & \\
Trial & $\mathrm{pH} 1$ & $\mathrm{pH} 8$ & $\mathrm{pH} 18$ & $\mathrm{pH} 28$ \\
\hline Control & 5.51 & 5.36 & $5.17 \mathrm{a}$ & 5.34 \\
Chryseobacterium sp. & 5.50 & 5.37 & $5.24 \mathrm{ab}$ & 5.31 \\
E. saccharominimus & 5.46 & 5.33 & $5.24 \mathrm{ab}$ & 5.33 \\
E. faecium & 5.52 & 5.36 & $5.24 \mathrm{ab}$ & 5.30 \\
Corynebacterium flavescens & 5.52 & 5.35 & $5.26 \mathrm{~b}$ & 5.37 \\
L. garvieae & 5.45 & 5.33 & $5.21 \mathrm{ab}$ & 5.28 \\
L. lactis & 5.34 & 5.24 & $5.20 \mathrm{ab}$ & 5.30 \\
Mixture & 5.32 & 5.25 & $5.21 \mathrm{ab}$ & 5.23 \\
p & $\mathrm{NS}$ & $\mathrm{NS}$ & $*$ & $\mathrm{NS}$ \\
\hline
\end{tabular}

All cheeses were manufactured with pasteurised milk inoculated with S. thermophilus and L. monocytogenes.

Control: no inoculation of other bacteria, Trial: inoculation with single bacterium, Mixture: inoculation with 6 bacterial species.

The values are the mean of 2 experiments. In the same column, letters ( $a, b$ and c) indicate homogeneous statistical processing groups. Numbers with different letters are not equal. $\mathrm{a}, \mathrm{b}$ and $\mathrm{c}$ are classified in increasing order $(\mathrm{a}<\mathrm{b}<\mathrm{c})$. Means in the same column with different letters were significantly different according to Newman-Keuls statistical test. $p=$ the significance levels (NS $=$ nonsignificant, $*=p<0.05, * *=p<0.01)$.

AI: area of inhibition.

$\mathrm{AI}=(\mathrm{t} 2-\mathrm{t} 1) / 2 \times\left[\left(C_{\mathrm{t} 2}+C_{\mathrm{t} 1}\right)-\left(T_{\mathrm{t} 2}+T_{\mathrm{t} 1}\right)\right]$

where $C=$ count of L. monocytogenes in control cheese inoculated with $S$. thermophilus and $T=$ count of $L$. monocytogenes in trial cheese inoculated with $S$. thermophilus and other bacterial species.

$\mathrm{t} 1$ and $\mathrm{t} 2=\mathrm{two}$ days of ripening. $\mathrm{AI}(\mathrm{t} 2-\mathrm{t} 1)$ : area of inhibition between two days of ripening.

Further studies, including more accurate determination of the anti-listerial metabolites produced, are needed to achieve a better understanding of L. monocytogenes in cheeses.

\section{Acknowledgements}

The authors are indebted to ARILAIT RECHERCHES and CNIEL (Centre National Interprofessionnel de l'Economie Laitière) for intellectual and financial support. They also sincerely thank Saint-Nectaire trade cheese. This work was financially supported by the AQS program of the French Ministry of Agriculture. English proofreading by Philip Rousseau-Cunningham and Harriet Colman.

\section{References}

AFNOR, 1985. Directives générales pour le dénombrement sans revivification des Enterobacteriaceae. Technique NPP et méthode par comptage des colonies. Standard NF V 08-021. Association Française de Normalisation (AFNOR).
AFNOR, 1988. Viandes et produits à base de viande. Dénombrement des Pseudomonas. Standard NF V 04-054. Association Française de Normalisation (AFNOR).

Buyong, N., Kok, J., Luchansky, J.B., 1998. Use of a genetically enhanced, pediocin-producing starter culture, Lactococcus lactis subsp. lactis MM217, to control Listeria monocytogenes in Cheddar cheese. Applied and Environmental Microbiology 64, 4842-4845.

Cocolin, L., Innocente, N., Biasutti, M., Comi, G., 2004. The late blowing in cheese: a new molecular approach based on PCR and DGGE to study the microbial ecology of the alteration process. International Journal of Food Microbiology 90, 83-91.

De Buyser, M.L., Lombard, B., Schulten, S.M., In’t Veld, P.H., Scotter, S.L., Rollier, P., Lahellec, C., 2003. Validation of EN ISO standard methods 6888 part 1 and part 2: 1999 - enumeration of coagulase-positive staphylococci in foods. International Journal of Food Microbiology 83, 185-194.

Delbes, C., Godon, J.J., Moletta, R., 1998. 16S rDNA sequence diversity of a culture-accessible part of an anaerobic digestor bacterial community. Environmental Microbiology 4, 267-275.

Denis, C., Gueguen, M., Henry, E., Levert, D., 2001. New media for the numeration of cheese surface bacteria. Lait 81, 365-379.

Duthoit, F., Godon, J.J., Montel, M.C., 2003. Bacterial community dynamics during production of Registered Designation of Origin Salers cheese as evaluated by $16 \mathrm{~S}$ rRNA gene Single Strand Conformation Polymorphism analysis. Applied and Environmental Microbiology 69, 3840-3848.

Duthoit, F., Callon, C., Tessier, L., Montel, M.-C., 2005. Relationships between sensorial characteristics and microbial dynamics in "Registered Designation of Origin" Salers cheese. International Journal of Food Microbiology 103, 259-270.

Ennahar, S., Deschamps, N., 2000. Anti-Listeria effect of enterocin A, produced by cheese isolated Enterococcus faecium EFM01, relative to other bacteriocins from lactic acid bacteria. Journal of Applied Microbiology 88, 449-457.

Ercolini, D., Mauriello, G., Blaiotta, G., Moschetti, G., Coppola, S., 2004. PCRDGGE fingerprints of microbial succession during a manufacture of traditional water buffalo mozzarella cheese. Journal of Applied Microbiology 96, 263-270.

Gay, M., Amgar, A., 2005. Factors moderating Listeria monocytogenes growth in raw milk and soft cheese made from raw milk. Lait 85, 153-170.

Godon, J.J., Zumstein, E., Dabert, P., Habouzit, F., Moletta, R., 1997. Molecular microbial diversity of an anaerobic digestor as determined by small-subunit rDNA sequence analysis. Applied and Environmental Microbiology 63, 2802-2813.

Gravesen, A., Jydegaard Axelsen, A.M., Mendes da Silva, J., Hansens, T.B., Knochel, S., 2002. Frequency of bacteriocin resistance development and associated fitness costs in Listeria monocytogenes. Applied and Environmental Microbiology 68, 756-764.

Hicks, S.J., Lund, B.M., 1991. The survival of Listeria monocytogenes in cottage cheese. Journal of Applied Bacteriology 70, 308-314.

IDF, 1991. Milk and milk products. Microorganisms. Colony Count at $30{ }^{\circ} \mathrm{C}$. IDF Standard 100B. International Dairy Federation.

Isolini, D., Grand, M., Glättli, H., 1990. Selektivmedien zum Nachweis von obligat und fakultativ heterofermentativen Laktobazillen. Schweizerische Milchwirtschaftliche Forschung 19, 57-59.

Loessner, M., Guenther, S., Steffan, S., Scherer, S., 2003. A pediocin-producing Lactobacillus plantarum strain inhibits Listeria monocytogenes in a multispecies cheese surface microbial ripening consortium. Applied and Environmental Microbiology 69, 1854-1857.

Maisnier-Patin, S., Deschamps, N., Tatini, S.R., Richard, J., 1992. Inhibition of Listeria monocytogenes in Camembert cheese made with a nisin-producing starter. Lait 72, 249-263.

Maoz, A., Mayr, R., Scherer, S., 2003. Temporal stability and biodiversity of two complex antilisterial cheese-ripening microbial consortia. Applied and Environmental Microbiology 69, 4012-4018.

Mayeux, J.V., Sandine, W.E., Elliker, P.R., 1962. A selective medium for detecting Leuconostoc in mixed-strain starter cultures. Journal of Dairy Science 45, 655 .

Millet, L., Didienne, R., Tessier, L., Montel, M.C., 2006. Control of Listeria monocytogenes in raw milk cheeses. International Journal of Food Microbiology 108, 105-114. 
Morgan, F., Bonnin, V., Mallereau, M.-P., Perrin, G., 2001. Survival of Listeria monocytogenes during manufacture, ripening and storage of soft lactic cheese made from raw goat milk. International Journal of Food Microbiology 64, 217-221.

Nunez, M., Rodriguez, J.L., Garcia, E., Gaya, P., Medina, M., 1997. Inhibition of Listeria monocytogenes by enterocin 4 during the manufacture and ripening of Manchego cheese. Journal of Applied Microbiology 83, $671-677$.

Ogier, J.-C., Lafarge, V., Girard, V., Rault, A., Maladen, V., Gruss, A., Leveau, J.-Y., Delacroix-Buchet, A., 2004. Molecular fingerprinting of dairy microbial ecosystems by use of temporal temperature and denaturing gradient gel electrophoresis. Applied and Environmental Microbiology 70, 5628-5643.

Olasupo, N.A., Schillinger, U., Narbad, A., Dodd, H., Holzapfel, W.H., 1999. Occurrence of nisin $\mathrm{Z}$ production in Lactococcus lactis BFE 1500 isolated from wara, a traditional Nigerian cheese product [in process citation]. International Journal of Food Microbiology 53, 141-152.

Pitt, W.M., Harden, T.J., Hull, R.R., 2000. Behavior of Listeria monocytogenes in pasteurized milk during fermentation with lactic acid bacteria. Journal of Food Protection 63, 916-920.

Ramsaran, H., Chen, J., Brunke, B., Hill, A., Griffiths, M.W., 1998. Survival of bioluminescent Listeria monocytogenes and Escherichia coli O157:H7 in soft cheeses. Journal of Dairy Science 81, 1810-1817.

Rodriguez, E., Calzada, J., Arques, J.L., Rodriguez, J.M., Nunez, M., Medina, M., 2005. Antimicrobial activity of pediocin-producing Lactococcus lactis on
Listeria monocytogenes, Staphylococcus aureus and Escherichia coli O157: H7 in cheese. International Dairy Journal 15, 51-57.

Slanetz, L.C.W., Bartley, C.H., 1957. Numbers of enterococci in water, sewage and feces determinated by the membrane filter technique with an improved medium. Journal of Bacteriology 74, 591-596.

Tagg, J.R., McGiven, A.R., 1971. Assay system for bacteriocins. Applied Microbiology 21, 943.

Terzaghi, B.E., Sandine, W.E., 1975. Improved medium for lactic streptococci and their bacteriophages. Applied Microbiology 29, 807-813.

Turner, N., Sandine, W.E., Elliker, P.R., Day, E.A., 1963. Use of tetrazolium dyes in an agar medium for differentiation of Streptococcus lactis and Streptococcus cremoris. Journal of Dairy Science 46, 380-385.

Vogensen, F.K., Karst, T., Larsen, J.J., Kringelum, B., Ellekjaer, D., Nielsen, E.W., 1987. Improved direct differentiation between Leuconostoc cremoris, Streptococcus lactis subsp. diacetylactis, and Streptococcus cremoris/Streptococcus lactis on agar. Milchwissenschaft 42, 646-648.

Wenzel, J.M., Marth, E.H., 1990. Changes in populations of Listeria monocytogenes in a medium with internal $\mathrm{pH}$ control containing Streptococcus cremoris. Journal of Dairy Science 73, 3357-3365.

Zumstein, E., Moletta, R., Godon, J.J., 2000. Examination of two years of community dynamics in an anaerobic bioreactor using fluorescence polymerase chain reaction (PCR) Single-Strand Conformation Polymorphism analysis. Environmental Microbiology 2, 69-78. 